\title{
PERBANDINGAN SENSITIVITAS CO-AMOXICLAV DAN OFLOXACIN TERHADAP KUMAN AEROB PENYEBAB OTITIS MEDIA SUPURATIF KRONIS DI RSUD PROVINSI NTB
}

\author{
I Gusti Ngurah Bagus Oka Juniawan*, Gusti Ayu Trisna**,Herlinawati*** \\ Fakultas Kedokteran Universitas Islam Al-Azhar \\ Jl. Unizar No.20 Turida Mataram \\ Email: herlinawati@unizar.ac.id
}

\begin{abstract}
ABSTRAK
Otitis media supuratif kronis merupakan infeksi kronis di telinga tengah dengan perforasi membran timpani dan sekret yang keluar dari telinga tengah terus-menerus atau hilang timbul dan salah satu penyakit yang sering ditemukan pada telinga. Otitis media supuratif kronis sering disebabkan oleh kuman aerob. Dalam penanganannya dapat diberikan antibiotik, beberapa antibiotik yang sering digunakan adalah co-amoxiclav dan ofloxacin. Tujuan penelitian adalah membandingkan sensitivitas co-amoxiclav dan ofloxacin terhadap kuman aerob penyebab otititis media supuratif kronis di RSUD Provinsi NTB. Metode Penelitian ini menggunakan desain jenis analitik observasional dengan pendekatan cross sectional. 50 pasien otitis media supuratif kronis diswab untuk pengambilan sekret telinga dengan metode pengambilan sampel purposive sampling. Uji sensitivitas antibiotik diuji dengan metode dilusi. Data dianalisis menggunakan uji Paired Samples Test dengan tingkat signifikasi $\mathrm{p}<0,05$.Dari 50 pasien didapatkan penyebab otitis media supuratif kronis terbanyak adalah Pseudomonas Aeruginosa (32,0\%). Co-amoxiclav sensitif terhadap gram positif $(26,0 \%)$ dan gram negatif $(14,0 \%)$ dengan total $40,0 \%$. Ofloxacin sensitif terhadap gram positif $(24,0 \%)$ dan gram negatif $(46,0 \%)$ dengan total $70,0 \%$. Dari hasil uji didapatkan $p$-value $0,000(\mathrm{p}<0,05)$, yang berarti terdapat perbedaan bermaknasensitivitas coamoxiclav dan ofloxacin terhadap kuman aerob penyebab otitis media supuratif kronis.
\end{abstract}

Kata Kunci :Co-Amoxiclav, Ofloxacin, Otitis Media Supuratif Kronis, Kuman Aerob.

\section{PENDAHULUAN}

Telinga merupakan salah satu organ tubuh manusia yang paling penting, berperan dalam proses pendengaran dan keseimbangan, sehingga apabila mempengaruhi kualitas hidup dan sosial ekonomi. Salah satu penyakit yang sering ditemukan pada telinga adalah Otitis Media Supuratif Kronis (OMSK). OMSK merupakan infeksi kronis di telinga tengah dengan perforasi membran timpani dan sekret yang keluar dari telinga tengah terus-menerus atau hilang timbul. Sekret mungkin encer, kental, bening, atau berupa nanah (Soepardi, 2014). OMSK diawali dengan terjadinya OMA (Otitis Media Akut). OMA dapat menjadi
OMSK, apabila terapi terlambat diberikan, terapi tidak adekuat, virulensi kuman tinggi, daya tahan tubuh pasien rendah, atau higienitas buruk (Djaafar, 2014).

Penyakit OMSK hingga saat ini masih menjadi masalah kesehatan dunia, yang masih dijumpai secara luas diberbagai negara. Prevalensi penderita OMSK di seluruh dunia didapatkan 5.888.576.000 total populasi. Jumlah penderita OMSK terbanyak terdapat di Afrika sebanyak 2.601.783.000 (44,1\%), Pasifik Barat 1.651.154.000 (28\%), Eropa $870.128 .000 \quad(14,7 \%), \quad$ Amerika 802.811 .000 (13,6\%), dan Mediterania Timur 473.644.000 (8\%). Sedangkan, di 
Asia Tenggara didapatkan 1.485.056.000 $(25,2 \%)$ populasi dengan 57.900 .000 $(3,8 \%)$ diantaranya mengalami gangguan pendengaran sebagai dampak dari OMSK (WHO, 2004).

Di negara berkembang kejadian OMSK cukup tinggi karena kurangnya higienitas dan penanganan dibandingkan negara maju. Dari hasil penelitian yang dilakukan sebelumnya, diperkirakan prevalensi penderita OMSK di Indonesia 5,4\%(Mahadevan, 2012). Sementara, di RSUD Provinsi NTB dari Januari November 2017 didapatkan jumlah penderita OMSK sebanyak 187 orang (RSUD Provinsi, 2017).

Hasil penelitian yang dilakukan di Bangalore, India,didapatkan jenis kuman penyebab OMSK terbanyak adalah Pseudomonas Aeruginosa (37,21\%) dan Staphylococcus Aureus (27,91\%)(Balan, 2017). Menunjukkan hasil yang sama pada penelitian yang lain, dengan didapatkan Staphylococcus Aureus (47,36\%) dan Pseudomonas Aeruginosa (26,31\%) (Asima, 2017).

Salah satu terapi antibiotik yang dapat dan sering digunakan dalam pengobatan OMSK adalah co-amoxiclav, karena dapat ditoleransi dengan baik, penyerapan baik melalui oral, serta penghambat bakteri penghasil enzim laktamase (Donati, 2017). Antibiotik lainnya, ofloxacin, karena sifat antipseudomonal yang dimiliki, resistensi Jurnal Kedokteran Vol. 05 No. 02 Juni 2020 bakteri minimal, dan kurangnya sifat ototoksik (Mehta, 2017). Co-amoxiclav merupakan kombinasi amoksisilin dan asam klavulanat. Amoksisilin bekerja dengan cara menghambat pertumbuhan bakteri dengan menganggu reaksi transpeptidasi sintesis dinding sel bakteri, sedangkan asam klavulanat melindungi amoksisilin dari enzim beta laktamase. Ofloxacin menghambat pembentukan DNA bakteri dengan menghambat topoisomerase IIdan topoisomerase IV (Katzung, 2014).

Hasil penelitian yang dilakukan di Gezira, Sudan,didapatkan sensitivitas coamoxiclav terhadap Staphylococcus Aureus (45\%),dan Pseudomonas Aeruginosa (26\%) (Elmustafa, 2016). Sedangkan, penelitian terbaru menunjukkan sensitivitas co-amoxiclav terhadap Staphylococcus Aureus $(71,4 \%)$ (Khan, 2017).

Hasil penelitian yang dilakukan di RSUP dr. M. Djamil, Padang, dari 79 isolasi sampel Pseudomonas Aeruginosa, ofloxacin menunjukkan resisten (38\%), intermediet $(1,27 \%)$, dan sensitif (68,35\%) (Rustini, 2016). Sedangkan, penelitian terbaru menunjukkan ofloxacin memiliki sensitivitas terhadap Staphylococcus Aureus (72\%)(Agrawal, 2017).

Hingga saat ini belum terdapat penelitian mengenai sensitivitas coamoxiclav dan ofloxacin terhadap kuman 
aerob penyebab OMSK di NTB. Sehingga perlu dilakukan penelitian, mengingat OMSK merupakan penyakit yang sering ditemukan pada telinga.

Berdasarkan uraian diatas, maka perlu dilakukan penelitian mengenai perbandingan sensitivitas co-amoxiclav dan ofloxacin terhadap kuman aerob penyebab otitis media supuratif kronis di RSUD Provinsi NTB.

\section{METODE PENELITIAN}

Jenis penelitian ini adalah analitik observasional dengan pendekatan cross sectional.Penelitian ini dilaksanakan di Poli Klinik RSUD Provinsi NTB dan Laboratorium Mikrobiologi RSUD Provinsi NTB.

Waktu

penelitiandilaksanakan pada FebruariMaret2018.Populasi penelitian ini adalah seluruh penderita otitis media supuratif kronis yang melakukan pemeriksaan di Poli Klinik RSUD Provinsi NTB pada bulan Februari dan Maret 2018.dan sampel penelitian adalah sekret telinga.Dalam peneltian ini metode pengambilan sampel yang digunakan adalah purposive sampling. Jumlah sampel yang dilibatkan sebanyak 50 orang. Data yang dipergunakan sesuai dengan kriteria inklusi dan eksklusi. Variabel bebas dalam penelitian ini adalah Co-Amoxiclav dan Ofloxacin sedangkan variabel terikat adalah Kuman Aerob.
Alat yang digunakan dalam penelitian ini adalah:Lidi Kapas Steril, Cawan Petri, Inkubator, Kaca Obyek, Lampu Spritus, Mikroskop, Tabung Reaksi Steril, Sungkup Lilin (Desikator), Ose. Sedangkan bahan: Sekret Telinga, Alkohol 70\%, Mc Conkey Agar (MCA) (Komposisi MCA: Pepton Yeast Extract 17 G, Agar 13,5 G, Protease Pepton 3 G, Netral Red 0,03 G, Lactosa 10 G, Crystal Violet 0,001 G, Bile Salt 1,5 G, Aquadest 1000 Ml, Sodium Cloride 5 G), Disk Antibiotik (Co-Amoxiclav dan Ofloxacin), Muller Hinton Agar (MHA) (Komposisi MHA: Meat, Infusion Solids From 300g 2g, Casein Acid Hydrolysate 17,5 G, Starch 1,5 G, Agar 17 G), Standar Kekeruhan Kuman Mc Farland 0,5 ( Bacl2 1\% dan $\mathrm{H} 2 \mathrm{SO} 4$ 1\%).

Pengambilan sampel penelitian: mempersiapkan lidi kapas steril, menjelaskan tujuan dan meminta persetujuan pengambilan sekret kepada pasien yang sudah didiagnosis OMSK oleh dokter spesialis THT,Peneliti menghadap ke telinga pasien,Kemudian melakukan fiksasi pada telinga pasien dan mengambil sekret menggunakan lidi kapas steril.

Diusapkan dengan cara digoreskan kedalam media isolasi Mc Conkey Agar, Tutup rapat dan diberi label, kemudian di bawa ke Laboratorium Mikrobiologi untuk pemeriksaan selanjutnya (Chairlan, 2011). 
Identifikasi bakteri: (a) pewarnaan

basa: siapkan kaca benda lalu teteskan aquades diatasnya, membuat apusan bakteri yang akan diamati dengan menggunakan inokulum, teteskan metilen blue diatasnya biarkan selama 60 detik, keringkan dengan cara serap air yang masih menggenang dengan menggunakan kertas hisap. (b) pewarnaan asam: Siapkan kaca benda lalu teteskan aquades diatasnya, buat apusan bakteri dengan menggunakan jarum inokulum, Tetesan larutan eosin diatas apusan, Ratakan campuran tersebut dengan menggunakan kaca benda, Keringkan selama 60 detik, Amati dibawah perbesaran mikroskop (FST UIN Malang, 2016). (c) Pewarnaan gram negatif dan gram positif: Siapkan kaca benda lalu teteskan aquades diatasnya, buat apusan dari dua biakan bakteri dengan menggunakan jarum inokulum, Difiksasi diatas api bunsen selama 5 detik. Teteskan larutan kristal violet diatasnya. Kemudian biarkan selama 60 detik. Siram dengan aquades. Teteskan iodium di atas kaca benda kemudian diamkan selama 60 detik. Teteskan alkohol 70\% diatasnya kemudian diamkan selama 30 detik. Teteskan larutan safranin kemudian diamkan selama 60 menit. Teteskan aquades diatasnya. Serap air yang menggenang diatas kaca benda dengan kertas serap. Amati dibawah perbesaran mikroskop (FST UIN Malang, 2016).

Jurnal Kedokteran

Vol. 05 No. 02 Juni 2020
p-ISSN 2460-9749

Uji sensitivitas bakteri: Biakan bakteri yang berumur 24 jam ditanam pada 2,5 $\mathrm{ml}$ kaldu MuellerHilton.Sesuaikan kekeruhannya dengan Nephelometer McFarland 0,5 (sesuai dengan jumlah bakteri $10^{7}-10^{8} / \mathrm{ml}$ ). Usap kapas steril dicelupkan ke dalam suspensi bakteri tersebut dengancara menekan dan memutar usap kapas pada dinding tabung sebanyak dua kali, lalu usapkan pada lempeng agar MuellerHilton dengan cara membuat garis rapat dan sejajar, putar lempeng $60^{\circ}$ dan lakukan hal yang sama sampai 3 kali sehingga biakan bakteri merata pada seluruh permukaan agar. Biakan bakteri pada lempeng agar ini dibiarkan mengering selama 4-5 menit.Letakkan cakram antibiotik pada lempeng agar dengan menggunakan pinset atau dispenser disk, kemudian diinkubasi $\quad 35^{\circ} \mathrm{C} \quad$ selama $\quad 18-24$ jam.Perhatikan ada tidaknya zona hambat yang terbentuk di sekitar cakram antibiotik. Bila ada zona hambat, ukur diameternya dengan kaliper/penggaris (FK UI, 2012).

Analisis hasil penelitian: Data yang diperoleh dalam penelitian ini diuraikan secara deskriptif dan dalam bentuk tabel. Data variabel co-amoxiclav dan ofloxacin dianalisis menggunakan uji Paired Samples Test dengan tingkat signifikasi $\mathrm{p}$ $<0,05$. Data yang telah terkumpul akan diolah dan dianalisis menggunakan software SPSS versi 24.0.

e-ISSN 2620-5890 


\section{HASIL DAN PEMBAHASAN}

\section{Hasil Penelitian}

Peneltiian ini dilakukan di Poli Klinik RSUD Provinsi NTB pada bulan Februari sampai Maret 2018. Sampel yang ditetapkan adalah sekret telinga pasien otitis media supuratif kronis di RSUD Provinsi NTB dengan total 50 sampel.

Karakteristik Pasien Berdasarkan Jenis Kelamin

Berdasarkan hasil penelitian, dari 50 pasien, didapatkan laki-laki sebanyak 30 orang $(60,0 \%)$ dan perempuan sebanyak 20 orang $(40,0 \%)$.

\section{Karakteristik Pasien Berdasarkan Kelompok Umur}

Berdasarkan hasil penelitian, dari 50 pasien, didapatkan pasien dengan umur 8-18 tahun sebanyak 44 orang (88,0\%), umur 19-29 tahun sebanyak 3 orang $(6,0 \%)$, dan umur $>30$ tahun sebanyak 3 orang $(6,0 \%$.).

\section{Identifikasi Jenis Kuman Aerob}

\section{Penyebab Otitis Media Supuratif Kronis}

Berdasarkan hasil identifikasi kuman aerob, didapatkan kuman penyebab otitis media supuratif kronis terbanyak adalah Pseudomonas Aeruginosa sebanyak 16 isolat (32,0\%), Proteus Mirabilis sebanyak 13 isolat (26,0\%), Staphylococcus Haemolyticus sebanyak 9 isolat $(18,0 \%)$, Staphylococcus Aureus sebanyak 6 isolat $(12,0 \%)$,

Enterobacter Aerogenessebanyak 2 isolat $(4,0 \%)$, Jurnal Kedokteran
Serratia Marcescens sebanyak 2 isolat (4,0\%), danKlebsiella Pneumonia sebanyak 2 isolat $(4,0 \%)$.

\section{Sensitivitas Co-Amoxiclav Terhadap}

\section{Kuman Aerob}

Berdasarkan hasil uji sensitivitas co-amoxiclav, didapatkan sensitif terhadap 13 isolat $(26,0 \%)$ gram positif dan 7 isolat $(14,0 \%)$ gram negatif dengan jumlah 20 isolat $(40,0 \%)$, intermediet terhadap 1 isolat $(2,0 \%)$ gram positif dan 6 isolat $(12,0 \%)$ gram negatif dengan jumlah 7 isolat $(14,0 \%)$, dan resisten terhadap 1 isolat $(2,0 \%)$ gram positif dan 22 isolat $(44,0 \%)$ gram negatif dengan jumlah 23 isolat $(46,0 \%)$. Hal ini menunjukkan bahwa co-amoxiclav memiliki sensitivitas yang lebih tinggi terhadap bakteri gram positif dibandingkan gram negatif.

\section{Sensitivitas Ofloxacin Terhadap Kuman}

Aerob

Berdasarkan uji sensitivitas ofloxacin, didapatkan sensitif terhadap 12 isolat $(24,0 \%)$ gram positif dan 23 isolat (46,0\%) dengan jumlah 35 isolat $(70,0 \%)$, intermediet terhadap 0 isolat $(0 \%)$ gram positif dan 8 isolat $(16,0 \%)$ gram negatif dengan jumlah 8 isolat $(8,0 \%)$, dan resiten terhadap 3 isolat $(6,0 \%)$ gram positif dan 4 isolat $(8,0 \%)$ gram negatif dengan jumlah 7 isolat $(14,0)$. Hal ini menunjukkan bahwa ofloxacin memiliki sensitivitas yang lebih tinggi terhadap 
bakteri gram negatif dibandingkan gram positif.

Perbandingan Sensitivitas CoAmoxiclav dan Ofloxacin

Berdasarkan distribusi sensitivitas antibiotik terhadap kuman aerob, didapatkan co-amoxiclav, sensitif terhadap 13 isolat $(26,0 \%)$ gram positif dan 7 isolat $(14,0 \%)$ gram negatif dengan jumlah 20 isolat $(40,0 \%)$, intermediet terhadap 1 isolat $(2,0 \%)$ gram positif dan 6 isolat $(12,0 \%)$ gram negatif dengan jumlah 7 isolat $(14,0 \%)$, dan resisten terhadap 1 isolat $(2,0 \%)$ gram positif dan 22 isolat $(44,0 \%)$ gram negatif dengan jumlah 23 isolat $(46,0 \%)$. Sedangkan, ofloxacin didapatkan, sensitif terhadap 12 isolat $(24,0 \%)$ gram positif dan 23 isolat $(46,0 \%)$ gram negatif dengan jumlah 35 isolat $(70,0 \%)$, intermediet terhadap 0 isolat $(0 \%)$ gram positifdan 8 isolat $(16,0 \%)$ gram negatif dengan jumlah 8 isolat $(8,0 \%)$, dan resiten terhadap 3 isolat $(6,0 \%)$ gram positif dan 4 isolat $(8,0 \%)$ gram negatif dengan jumlah 7 isolat $(14,0)$.

Berdasarkan hasil uji aired Samples Test diperolehnilai signifikasi $0,000 \quad(\mathrm{p}<0,05), \quad$ terjadi penolakan terhadap terhadap $\mathrm{H}_{0}$ dan penerimaan terhadap $\mathrm{H}_{\mathrm{a}}$, yang berartiterdapat perbedaan sensitivitas co-amoxiclav dan ofloxacin terhadap kuman aerob penyebab otitis media supuratif kronis di RSUD Provinsi NTB.

Jurnal Kedokteran

Vol. 05 No. 02 Juni 2020

\section{Pembahasan}

Hasil penelitian menunjukkan bahwa dari 50 pasien didapatkan, laki-laki sebanyak 30 orang $(60,0 \%)$ dan perempuan sebanyak 20 orang $(40,0 \%)$. Hal ini dapat disebabkan oleh kegiatan laki-laki yang lebih sering dilakukan di luar ruangan sehingga lebih mudah terinfeksi dan terpapar dengan kontaminan lingkungan (Dewi, 2013).

Hasil ini serupa dengan penelitian yang dilakukan di Medan, Indonesia oleh Yulius tahun 2017. Yang menunjukkan prevalensi laki-laki $(67,5 \%)$ lebih tinggi dibandingkan perempuan (32,5\%). Hal ini membuktikan bahwa laki-laki memiliki resiko lebih tinggi menderita otitis media supuratif kronis dibandingkan perempuan (Yulius, 2017).

Namun, menunjukkan hasil yang berbeda dengan penelitian yang dilakukan di Bangalore, India oleh Asima tahun 2017. Yang mendapatkan prevalensi lakilaki $(48,3 \%)$ dan perempuan $(51,7 \%)$ (Asima, 2017).

Berdasarkan kelompok umur, dari 50 pasien, didapatkan pasien terbanyak berumur 8-18 tahun sebanyak 44 orang $(88,0 \%)$, diikuti umur 19-29 tahun sebanyak 3 orang $(6,0 \%)$, dan umur $>30$ tahun sebanyak 3 orang $(6,0 \%)$. Hal ini dapat disebabkan, karena anak-anak cenderung memiliki higienitas dan perilaku sehat yang kurang, status imun yang rendah, dan memiliki tuba 
eustachius yang pendek dan horizontal sehingga memudahkan invasi kuman (Lubis, 2016).

Menunjukkan hasil yang serupa dengan penelitian yang dilakukan di Medan, Indonesia oleh Yulius tahun 2017, didapatkan kelompok umur 6-24 tahun sebanyak 23 pasien (57,5\%), diikuti umur 25-34 tahun sebanyak 13 pasien $(32,5 \%)$, umur $44-62$ tahun sebanyak 3 pasien $(7,5 \%)$, dan umur $>62$ tahun sebanyak 1 pasien (2,5\%), yang menyatakan bahwa kelompok umur anakanak dan dewasa muda lebih beresiko menderita OMSK (Yulius, 2017).

Namun, menunjukkan hasil yang berbeda dengan penelitian yang dilakukan di Lusaka, Zambia oleh Phiri tahun 2016. Yang mendapatkan pasien otitis media supuratif kronis terbanyak berumur $>18$ tahun (67\%), sedangkan $<18$ tahun $(33 \%)$ (Phiri, 2016).

Berdasarkan hasil identifikasi kuman aerob, didapatkan kuman penyebab otitis media supuratif kronis terbanyak adalah Pseudomonas Aeruginosa sebanyak 16 isolat (32,0\%), diikuti Proteus Mirabilis sebanyak 13 isolat (26,0\%), Staphylococcus Haemolyticus sebanyak 9 isolat $(18,0 \%)$, Staphylococcus Aureus sebanyak 6 isolat (12,0\%), Enterobacter Aerogenes sebanyak 2 isolat (4,0\%), Serratia Marcescens sebanyak 2 isolat (4,0\%), danKlebsiella Pneumonia sebanyak 2 Jurnal Kedokteran Vol. 05 No. 02 Juni 2020 p-ISSN 2460-9749

isolat $(4,0 \%)$. Hal ini dapat terjadi, karena perbedaan iklim dan letak geografis yang mempengaruhi tumbuhnya kuman (Phiri, 2016).

Hasil ini serupa dengan penelitian, yang dilakukan di Rajashtan, India oleh Agrawal tahun 2017. Yang menunjukkan kuman terbanyak penyebab otitis media supuratif kronis adalah Pseudomonas Aeruginosa (41.1\%), diikuti Staphylococcus Aureus $(38,7 \%)$,Coagulase Negatif Staphylococcus (8,5\%),Proteus Vulgaris (3.1\%), Escherichia Coli (2,3\%), dan Proteus Mirabilis (1,5\%) (Agrawal, 2017).

Namun, menunjukkan hasil yang berbeda dengan penelitian yang dilakukan di Lusaka, Zambia oleh Phiri tahun 2016. Yang menunjukkan kuman penyebab otitis media supuratif kronis terbanyak adalah Proteus Mirabilis (29,0\%), diikuti Pseudomonas Aeruginosa (18,9\%), dan Coagulase negatif Staphylococcus $(20,1 \%)$ (Phiri, 2016).

Berdasarkan hasil penelitian perbandingan sensitivitas antibiotik terhadap kuman aerob, didapatkan coamoxiclav, sensitif terhadap 13 isolat gram negatif dengan jumlah 20 isolat $(40,0 \%)$, intermediet terhadap 1 isolat $(2,0 \%)$ gram positif dan 6 isolat $(12,0 \%)$ gram negatif dengan jumlah 7 isolat $(14,0 \%)$, dan resisten terhadap 1 isolat e-ISSN 2620-5890 $(26,0 \%)$ gram positif dan 7 isolat $(14,0 \%)$ 
$(2,0 \%)$ gram positif dan 22 isolat $(44,0 \%)$ gram negatif dengan jumlah 23 isolat $(46,0 \%)$. Sedangkan, ofloxacin didapatkan, sensitif terhadap 12 isolat (24,0\%) gram positif dan 23 isolat $(46,0 \%)$ dengan jumlah 35 isolat $(70,0 \%)$, intermediet terhadap 0 isolat $(0 \%)$ gram positif dan 8 isolat $(16,0 \%)$ gram negatif dengan jumlah 8 isolat $(8,0 \%)$, dan resiten terhadap 3 isolat $(6,0 \%)$ gram positif dan 4 isolat $(8,0 \%)$ gram negatif dengan jumlah 7 isolat $(14,0)$. Hal ini menunjukkan, bahwa terdapat perbedaan terhadap sensitivitas co-amoxiclav dan ofloxacin terhadap kuman aerob penyebab otitis media supuratif kronis.

Penelitian ini menunjukkan bahwa sensitivitas ofloxacin lebih tinggi dibandingkan co-amoxiclav, hal ini ditunjukkan dari 50 sampel, didapatkan ofloxacin sensitif terhadap 12 isolat $(24,0 \%)$ gram positif dan 23 isolat $(46,0 \%)$ gram negatif dengan jumlah 35 isolat $(70,0 \%)$. Sedangkan, co-amoxiclav, didapatkan sensitif terhadap 13 isolat $(26,0 \%)$ gram positif dan 7 isolat $(14,0 \%)$ gram negatif dengan jumlah 20 isolat $(40,0 \%)$. Perbedaan sensitivitas antibiotik, dapat dipengaruhi oleh, difusi antimikroba pada sel dan jaringan hospes, protein serum pengikat antimikroba, gangguan dan interaksi obat, status daya tahan dan sistem imun pasien, mengidap beberapa penyakit secara bersamaan, virulensi dan patogenitas bakteri yang

Jurnal Kedokteran

Vol. 05 No. 02 Juni 2020 menginfeksi, tempat infeksi, dan keparahan penyakit (Soleha, 2015).

Menunjukkan hasil yang serupa dengan penelitian yang dilakukan di Andhra Pradesh, India oleh Rao tahun 2014. Didapatkan bahwa ofloxacin memiliki sensitivitas yang tinggi terhadap Pseudomonas Aeruginosa yang merupakan bakteri gram negatif $(89,65 \%)$ dibandingkan co-amoxiclav $(20,6 \%)$ yang memiliki sensitivitas yang lebih rendah (Rao, 2014). Penelitian lainnya juga menunjukkan bahwa ofloxacin memiliki sensitivitas yang tinggi terhadap Pseudomonas Aeruginosa (68,35\%) (Rustini, 2016), sedangkan co-amoxiclav memiliki sensitivitas yang rendah terhadap Pseudomonas Aeruginosa(26\%) (Elmustafa, 2016).

\section{PENUTUP \\ SIMPULAN}

1. Kuman aerob penyebab otitis media supuratif kronis adalah Pseudomonas Aeruginosa sebanyak 16 isolat (32,0\%), Proteus Mirabilis sebanyak 13 isolat (26,0\%), Staphylococcus Haemolyticus sebanyak 9 isolat (18,0\%), Staphylococcus Aureus sebanyak 6 isolat (12,0\%), Enterobacter Aerogenes sebanyak 2 isolat (4,0\%), Serratia Marcescens sebanyak 2 isolat $(4,0 \%)$, danKlebsiella Pneumonia sebanyak 2 isolat $(4,0 \%)$.

p-ISSN 2460-9749 e-ISSN 2620-5890 
2. Sensitivitas co-amoxiclav, didapatkan sensitif terhadap 13 isolat $(26,0 \%)$ gram positif dan 7 isolat $(14,0 \%)$ gram negatif dengan total 20 isolat (40,0\%). Hal ini menunjukkan bahwa co-amoxiclav memiliki sensitivitas yang lebih tinggi terhadap bakteri gram positif dibandingkan gram negatif.

3. Sensitivitas ofloxacin, didapatkan sensitif terhadap 12 isolat $(24,0 \%)$ gram positif dan 23 isolat $(46,0 \%)$ gram negatif dengan total 35 isolat (70,0\%). Hal ini menunjukkan bahwa ofloxacin memiliki sensitivitas yang lebih tinggi terhadap bakteri gram negatif dibandingkan gram positif.

4. Berdasarkan hasil yang didapat, ofloxacin memiliki sensitivitas yang lebih tinggi dibandingan coamoxiclav dan didapatkan nilai signifikasi $0,000 \quad(\mathrm{p}<0,05), \quad$ yang berartiterdapat perbedaan yang bermakna sensitivitas co-amoxiclav dan ofloxacin terhadap kuman aerob penyebab otitis media supuratif kronis di RSUD Provinsi NTB.

\section{SARAN}

Dianjurkan untuk pengobatan otitis media supuratif kronis di RSUD Provinsi NTB yang disebabkan oleh gram negatif, ofloxacin lebih dianjurkan dibandingkan co-amoxiclav, karena memiliki sensitivitas yang lebih tinggi dan tersedia Jurnal Kedokteran dalam bentuk topikal untuk mengurangi ototoksik.

\section{DAFTAR PUSTAKA}

Agrawal, R., Khatri, P.K., Parihar, R.S., \& Shah, H. 2017. Microbial assessment of chronic suppurative otitis media in a tertiary care center of Rajasthan. International Journal of Health Sciences \& Research. vol. 7, no. 2, pp. 120-126.

Asima, B., Samhitha, V., Presteena, \& Karthik, S., 2017. Spectrum and Antibiogram of Bacteria in Chronic Suppurative Otitis Media and BiofilmFormation. Journal of Stem Cell Research \& Therapeutics. vol. 2, no. 4, pp 1-4.

Balan, S. \& Viswanatha, B. 2017. Microbiology of chronic suppurative otitis media: a prospective study in a tertiary care hospital. Journal of Otolaryngology-ENT Research. vol. 9, no. 1, pp. 1-4.

Basmajian, J.V., \& Slonecker, C.E. 2010. Anatomi klink. Jakarta: Binarupa Aksara.

Brooks, G.F., Butel, J.S., \& Morse, S.A. 2005. Mikrobiologi Kedokteran. Jakarta: Penerbit Buku Kedokteran EGC.

Chairlan, \& Lestari, E. 2011. Pedoman teknik dasar untuk laboratorium kesehatan ed. 2. Jakarta: Penerbit Buku Kedokteran EGC.

Clinical Laboratory Standards Institute. 2013. M100-S23 Perfomance Standards for Antimicrobal Susceptibility Testing: Twenty-Third Informational Supplement. Pensylvania: Clinical Laboratory Standards Institute.

Darad, H., \& Sinha, M. 2017. retrospective study. International Journal of Otorhinolaryngology and Head and Neck Surgery. vol. 3, no.2, pp. 234-238. Aetiological factor for chronic suppurative otitis media: a 
Departemen Kesehatan Republik Indonesia. 2014. Panduan praktik klinis bagi dokter di fasilitas pelayanan kesehatan primer. Jakarta: Departemen Kesehatan Republik Indonesia.

Departemen Mikrobiologi Fakultas Kedokteran Universitas Indonesia. 2012. Penuntun praktikum mikrobiologi kedokteran. Jakarta: Badan Penerbit Fakultas Kedokteran Universitas Indonesia.

Devnath, P., Uddin, K., Ahamed, F., Hossain, T., \& Manchur, M.A. 2017. Extraction, purification, and characterization of pyocyanin produced by Pseudomonas aeruginosa and evaluation for its antimicrobial activity. International Research Journal of Biological Sciences. vol. 6, no. 5, pp 1-9.

Dewi, N.P., \& Zahara, D. 2013. Characteristic of chronic suppurative otitis media at $\mathrm{H}$. Adam Malik Hospital Medan. E-Journal FK USU. vol. 1, no. 2, pp. 1-6.

Djaafar, Z.A., Helmi, \& Restuti, R.D. 2014. Kelainan telinga tengah dalam Soepardi E.A., Iskandar, N., Bashiruddin, J., \& Restuti R.D. Buku Ajar Ilmu Kesehatan Telingga, Hidung, Tenggorokan, Kepala, \& Leher ed. 7. Jakarta: Badan Penerbit Fakultas Kedokteran Universitas Indonesia.

Donati, M., Motola, D., Leone, R., Moretti, U., Stoppa, G., Arzenton, E., Lenti, M.C., Bonaiuti, R., Mugelli, A., Vannacci, A., Rafaniello, C., Sportiello, L., Capuano, A., Bortolami, O., \& Vaccheri, A. 2017. Liver Injury due to Amoxicillin vs. Amoxicillin/Clavulanate: A Subgroup Analysis of a DrugInduced Liver Injury Case-Control Study in Italy. Journal of Hepatology and Gastrointestinal Disorder. vol. 3, no. 1, pp. 1-5.

Elmustafa, M., Yousif, M.A., Osman, W.N., \& Elmustafa, O.M. 2016. Aerobic bacteria in safe type chronic suppurative otitis media in Gezira State, Sudan. Journal of Science and Technology. vol. 36, no. 1, pp. 1-6.

Fakultas Farmasi Universitas Sanata Dharma. 2016. Panduan praktikum mikrobiologi. Yogyakarta: Fakultas Farmaasi Universitas Sanata Dharma.

Fakultas Kedokteran Universitas Indonesia. 2012. Panduan praktikum mikrobiologi kedokteran. Jakarta: Fakultas Kedokteran Universitas Indonesia.

Ganiswara, S.G. 1995. Farmakologi dan terapi ed. 4. Jakarta: Badan Penerbit Fakultas Kedokteran Universitas Indonesia.

Katzung, B.G., Masters, S.B., \& Trevor, A.J. 2014. Farmakologi dasar \& klinik vol. 2. Jakarta: Penerbut Buku Kedokteran EGC.

Khan, T.Z., Aqeel, Z., \& Raheem, D. 2017. Sensitivity of antibiotics against Pseudomonas aeruginosa and Staphylococcus aureus in chronic suppurative otitis media. Rawal Medical Journal. vol. 42, no. 2, pp. 195-198.

Lubis, Y.M., Dharma, A., Chaidir, Z., Refilda, \& Fachrial, E. 2016. Profile of chronic suppurative otitis media patients with positive fungal culture in Medan, Indonesia. Journal of Chemical and Pharmaceutical Research. vol. 8, no. 1, pp. 23-26.

Mahadevan, M., Navarro-Locsin, G., Tan, H.K.K., Yamanaka, N., Sonsuwan, N., Wang, P.C., Dung, N.T.N., Restuti, R.D., Hashim, S.M.M., \& Vijayasekaran, S. 2012. A review of the burden of disease due to otitis media in the Asia-Pacific. International Journal of Pediatric Otorhinolaryngology. vol. 76, pp. 623-635.

Mehta, M., Saha, P., Kunkulol, R., Simar, H., \& Mehta, N. 2017. Microbiological Profile and Antibiotic Sensitivity Pattern of Active Mucosal Chronic Otitis Media and Active Squamous Chronic Otitis Media (with 
Cholesteatoma) in a Tertiary Care Hospital of Hisar, (Haryana) India. Annals of Clinical Otolaryngology. vol. 2, no. 3, pp. 1-6.

RSUD Provinsi NTB. 2017. Prevalensi penderita OMSK Januari-November 2017. Mataram: Litbangkes RSUD Provinsi NTB.

Sherwood, L. 2014. Fisiologi manusia dari sel ke sistem ed. 6. Jakarta: Penerbit Buku Kedokteran EGC.

Soleha, T.U. 2015. Uji kepekaan terhadap antibiotik. Juke Unila. vol. 5, no. 9, pp. 119-123.

Soetirto, I., Hendarmin, H., \& Bashiruddin, J. 2014. Gangguan pendengaran dan kelainan telinga dalam Soepardi E.A., Iskandar, N., Bashiruddin, J., \& Restuti R.D. Buku Ajar Ilmu Kesehatan Telingga, Hidung, Tenggorokan, Kepala, \& Leher ed. 7. Jakarta: Badan Penerbit Fakultas Kedokteran Universitas Indonesia.

Suhatri, Handayani, P., \& Harisman. 2017. Kajian drug related problems pasien otitis media supuratif kronis di bangsal THT RSUP. Dr. M. Djamil Padang. Jurnal Sains Farmasi \& Klinis. vol. 3, no. 2, pp. 172-177.

World Health Organization. 2004. Chronic suppurative otitis media Burden of Illness and Management Options. Geneva: World Health Organization.

Zhang, Y., Xu, M., Zhang, J., Zeng, L., Wang, Y., \& Zheng, Q.Y. 2014. Risk factors for chronic and recurrent otitis media-a metaanalysis. Plos One. vol. 9, no. 1, pp. $1-9$. 